\title{
Argumentative Strategies and Stylistic Devices
}

\author{
TON VAN HAAFTEN
}

Faculty of Humanities

Leiden University Centre for Linguistics (LUCL)

2300 RA Leiden

P.O. Box 9515

The Netherlands

t.van.haaften@hum.leidenuniv.nl

\begin{abstract}
The extended pragmadialectical argumentation theory assumes that people engaged in argumentative discourse manoeuvre strategically. In argumentative reality, the strategic manoeuvring is often carried out according to an argumentative strategy. Language users make an effort to present their strategic manoeuvres in a specific way and the analysis of the stylistic choices in actual argumentative discourse is the most important basis for identification and analysis of argumentative strategies. In this article, it is shown what requirements must be satisfied by a systematic stylistic analysis of argumentative discourse, and the results of such an analysis are illustrated by means of a case study.
\end{abstract}

Résumé: La théorie de l'argumentation pragma-dialectique détaillée suppose que les gens s'engagent dans des manœuvres de discours argumentatif de manière stratégique. Dans la réalité argumentative, la manœuvre stratégique se réalise souvent selon une stratégie argumentative. Les utilisateurs de langue s'efforcent de présenter leurs manœuvres stratégiques d'une manière spécifique et l'analyse des choix stylistiques dans le discours argumentatif réel constitue la base la plus importante pour l'identification et l'analyse des stratégies argumentatives. Dans cet article, on identifie les exigences qui doivent être remplies par une analyse stylistique systématique du discours argumentatif et on illustre les résultats d'une telle analyse au moyen d'une étude de cas.

Keywords: argumentative strategy, Cognitive Linguistics, construal, linguisticstylistic analysis, Pragma-Dialectical Argumentation Theory, strategic manoeuvring, stylistic device 


\section{Introduction}

The extended pragma-dialectical argumentation theory assumes that people engaged in argumentative discourse manoeuvre strategically. "Strategic manoeuvring" refers to the efforts arguers make in argumentative discourse to reconcile rhetorical effectiveness with the maintenance of dialectical standards of reasonableness. In order to not let one objective prevail over the other, the parties try to strike a balance between the different objectives at every discussion stage (confrontation, opening, argumentation and concluding stage) to resolve their differences of opinion. At the end of the $20^{\text {th }}$ century, van Eemeren and Houtlosser (e.g.1999a) developed the concept of strategic manoeuvring as a means of making the pragma-dialectical argumentation theory more accurate as an analytical tool.

There are three ways in which strategic manoeuvring manifests itself in argumentative discourse: (a) the choices that are made from the topical potential, (b) audience-directed framing of discussion moves and (c) the use of presentational devices. The choice made from the topical potential has to do with the perspective from which the arguer selects his discussion moves (van Eemeren 2010, pp. 96-108). Adaptation to the audience covers the attuning of the discussion moves to audience demand (van Eemeren 2010, pp. 108-118). The exploitation of presentational devices pertains to the communicative means that are used in presenting the discussion moves (van Eemeren 2010, pp. 118-127). Although these three aspects of strategic manoeuvring can be distinguished analytically, in actual argumentative practice they will usually be hard to disentangle.

Van Eemeren (2018, pp. 116-120) makes it clear that although the strategic manoeuvring taking place in an argumentative discourse may result in the occurrence of several separate and independent strategic manoeuvres that are unrelated to each other, in argumentative reality, the strategic manoeuvring may well be carried out according to a largely deliberate design where the various strategic manoeuvres are combined in such a way that they are likely to reinforce one another. If this happens more or less consistently in the discourse, the series of individual strategic 
moves involved constitutes an "argumentative strategy," that is, a coordinated and coherent effort to achieve, dialectically as well as rhetorically, the intended result. ${ }^{1}$

When manoeuvring strategically, speakers or writers make an effort to present their discussion moves in a specific way. In all stages of the critical discussion, their presentation of the moves may be assumed to be systematically attuned to achieving the strategic purposes they are aiming for. The wording or stylistic design of a discussion move is often the most important part of its strategic presentation. The analysis of strategic manoeuvring, therefore, has to take due account of the stylistic choices that have been made (van Eemeren 2010, pp. 118-119). The choice of a discussion move, the choice of an audience-directed frame, and the choice of presentational devices are all relevant dimensions in selecting an argumentative strategy. But presentational devices are the instances of its realization and hence of its retrieval in analysis (Fahnestock \& Tonnard 2011, p. 104). Thus, the analysis of the stylistic choices in actual argumentative discourse is often the most important basis for identification and analysis of argumentative strategies.

However, if the analysis of stylistic choices in argumentative discourse is to be an adequate method for identifying and analysing argumentative strategies, it will have to be conducted systematically and not on an ad hoc basis. In this article, I aim to show what requirements must be satisfied by a systematic stylistic analysis in the context of the pragma-dialectical argumentation theory (section 3) and will illustrate the results of such an analysis by means of a case study (section 4). But before doing this, I will first look more closely at the concept of argumentative strategy as developed and defined by van Eemeren $(2010 ; 2018)$ (section 2).

\footnotetext{
${ }^{1}$ Van Eemeren (2018, pp. 116-117) argues that employing an argumentative strategy involves both coordinating the consecutive strategic manoeuvres that are made and coordinating the choices made in each argumentative manoeuvre as regards the three aspects of strategic manoeuvring. In this article, I concentrate on the first type of coordination with respect to argumentative strategies.
} 


\section{Argumentative strategies}

As van Eemeren $(2010 ; 2018)$ correctly observes, it is important to give systematic attention to the various kinds of argumentative strategies, and the distinctions between them, in order to contribute to achieving a profound, realistic, and accurate reconstructive analysis and an adequate evaluation of argumentative discourse. As mentioned above, an argumentative strategy can be defined as a coordinated and coherent set of strategic manoeuvres put forward in argumentative discourse to achieve dialectically as well as rhetorically the result that is aimed for. In the case of a specific discussion (a speech event), of course, this desired result itself is also specific, but it can always be linked in some way to the dialectical and rhetorical dimensions of the four discussion stages distinguished within the pragma-dialectical argumentation theory. Figure 1 (taken from van Eemeren 2018, p. 116) shows the dialectical and rhetorical dimensions for the four discussion stages. 


\begin{tabular}{|c|c|c|c|c|c|}
\hline & Dialectical dimension & Rhetorical dimension & $\begin{array}{l}\text { Aspect of } \\
\text { topical choice }\end{array}$ & $\begin{array}{l}\text { Aspect of anticipat- } \\
\text { ing audience de- } \\
\text { mand }\end{array}$ & $\begin{array}{l}\text { Aspect of presentational } \\
\text { choice }\end{array}$ \\
\hline & Reasonableness & Effectiveness & $\begin{array}{l}\text { Reasonable and } \\
\text { effective topical } \\
\text { selection }\end{array}$ & $\begin{array}{l}\text { Reasonable and } \\
\text { effective handling of } \\
\text { audience demand }\end{array}$ & $\begin{array}{l}\text { Reasonable and effec- } \\
\text { tive use of presentation- } \\
\text { al devices }\end{array}$ \\
\hline Confrontation stage & $\begin{array}{l}\text { Reasonable definition of } \\
\text { difference of opinion }\end{array}$ & $\begin{array}{l}\text { Effective definition of } \\
\text { difference of opinion }\end{array}$ & $\begin{array}{l}\text { Reasonable and } \\
\text { effective choice of } \\
\text { issues and critical } \\
\text { responses }\end{array}$ & $\begin{array}{l}\text { Reasonable and } \\
\text { effective adjustment } \\
\text { of issues and critical } \\
\text { responses to audi- } \\
\text { ence }\end{array}$ & $\begin{array}{l}\text { Reasonable and effec- } \\
\text { tive presentational } \\
\text { design of issues and } \\
\text { critical responses }\end{array}$ \\
\hline Opening stage & $\begin{array}{l}\text { Reasonable establishment } \\
\text { of point of departure }\end{array}$ & $\begin{array}{l}\text { Effective establishment } \\
\text { of point of departure }\end{array}$ & $\begin{array}{l}\text { Reasonable and } \\
\text { effective choice of } \\
\text { procedural and } \\
\text { material starting } \\
\text { points }\end{array}$ & $\begin{array}{l}\text { Reasonable and } \\
\text { effective adjustment } \\
\text { of procedural and } \\
\text { material starting } \\
\text { points to audience }\end{array}$ & $\begin{array}{l}\text { Reasonable and effec- } \\
\text { tive presentational } \\
\text { design of procedural and } \\
\text { material starting points }\end{array}$ \\
\hline Argumentation stage & $\begin{array}{l}\text { Reasonable development } \\
\text { of lines of attack and } \\
\text { defence }\end{array}$ & $\begin{array}{l}\text { Effective development } \\
\text { of lines of attack and } \\
\text { defence }\end{array}$ & $\begin{array}{l}\text { Reasonable and } \\
\text { effective choice of } \\
\text { arguments and } \\
\text { criticisms }\end{array}$ & $\begin{array}{l}\text { Reasonable and } \\
\text { effective adjustment } \\
\text { of arguments and } \\
\text { criticisms to audi- } \\
\text { ence }\end{array}$ & $\begin{array}{l}\text { Reasonable and effec- } \\
\text { tive presentational } \\
\text { design of arguments and } \\
\text { criticisms }\end{array}$ \\
\hline Concluding stage & $\begin{array}{l}\text { Reasonable statement of } \\
\text { results }\end{array}$ & $\begin{array}{l}\text { Effective statement of } \\
\text { results }\end{array}$ & $\begin{array}{l}\text { Reasonable and } \\
\text { effective choice of } \\
\text { conclusion regard- } \\
\text { ing the results }\end{array}$ & $\begin{array}{l}\text { Reasonable and } \\
\text { effective adjustment } \\
\text { of conclusion } \\
\text { regarding the results } \\
\text { to audience }\end{array}$ & $\begin{array}{l}\text { Reasonable and effec- } \\
\text { tive design of presenta- } \\
\text { tion of conclusion } \\
\text { regarding the results }\end{array}$ \\
\hline
\end{tabular}

Figure 1. Reasonableness and effectiveness in argumentative discourse (taken from van Eemeren 2018, p. 116) 
Argumentative strategies are highly diverse in nature and are often also highly context-dependent. Specific institutional contexts, such as a court case, a political election debate or a parliamentary debate, for example, require specific argumentative strategies or make it possible to use specific argumentative strategies. But very specific situational characteristics of the context (for example, whether or not the person accused of a crime has already confessed) also require or enable specific argumentative strategies. In addition, argumentative strategies can either be used consistently through all stages of the discussion or in only one discussion stage, or somewhere between these extremes. You can also make a distinction between argumentative strategies that are intended to be effective in persuading the actual opponent in a discussion and those that are intended to be effective in persuading someone other than the actual opponent: a third party that is in fact the speaker's or writer's primary audience, as in the case of an election debate between politicians, for example.

Finally, a distinction can also be made between argumentative strategies that are specifically linked to a discussion stage and those that are not and are instead determined more situationally and institutionally. Besides more context-dependent argumentative strategies, ${ }^{2}$ there are also specific "confrontational strategies," "opening strategies," "argumentational strategies," and "concluding strategies" (van Eemeren 2010, pp. 46-47; 2018, pp. 116120). ${ }^{3}$

Although theoretical and empirical studies of argumentative strategies have already resulted in interesting outcomes, further research is needed in order to achieve a profound, realistic and accurate reconstructive analysis and an adequate evaluation of

\footnotetext{
${ }^{2}$ See van Eemeren (2018, pp. 118-120) for the discussion of a case study where a protagonist consistently uses a context-dependent argumentation strategy ("sustained conciliation") throughout all the discussion stages.

${ }^{3}$ A number of specific confrontational, opening, argumentational, and concluding strategies are identified in the literature (see e.g. van Eemeren 2010; 2018; van Eemeren \& Houtlosser 1999a; Fahnestock \& Tonnard 2011; van Poppel 2016; Snoeck Henkemans 2005a; 2008; 2017).
}

(C) Ton van Haaften. Informal Logic, Vol. 39, No. 4 (2019), pp. 301-328 
argumentative discourse. ${ }^{4}$ One possible research topic could be the way in which argumentative strategies are realized verbally.

\section{A linguistic-stylistic analysis of argumentative strategies}

Since van Eemeren \& Houtlosser introduced the concept of strategic manoeuvring (e.g. van Eemeren \& Houtlosser 1999a), interesting work has been carried out within this framework on the linguistic choices arguers make for formulating a discussion move in a reasonable but also effective way. ${ }^{5}$ Part of the research regarding the presentation of a discussion move concerns the supposed strategic effects of conspicuous stylistic choices such as figures of speech including metaphors, hyperbole, irony, praeteritio, rhetorical questions, amplification, etc. ${ }^{6}$ But, as van Eemeren (2010: 119) and others correctly point out, each stylistic choice-including the less conspicuous or non-conspicuous ones-serves the purpose of framing the argumentative move that is formulated in such a way as to introduce a particular perspective; the language choices at an arguer's disposal to enhance effectiveness can include virtually any non-exceptional language element (Perelman \& OlbrechtsTyteca 1969). Being aware of the power of seemingly nonexceptional language, the Pragma-Dialecticians have also studied ordinary language devices, as studies analyzing word choice,

\footnotetext{
${ }^{4}$ One of the interesting questions is, for example, whether-and, if so, howreasonable argumentative strategies can be distinguished from fallacious ones. Unfortunately, it is not possible within the scope of this article to explore this here (but see van Haaften in preparation, "How to argue reasonably and effectively with style in Dutch").

${ }^{5}$ Discussion moves can also be presented using a combination of verbal and visual means (multimodal presentation) or by visual means alone (e.g. Tseronis 2017). Tseronis argues convincingly that an empirically adequate description and explanation of argumentative reality must also include studying the use of semiotic modes other than the verbal and studying the way these modes combine in acts of arguing in support of a standpoint. In this article, however, I concentrate on the verbal presentation of argumentative strategies.

${ }^{6}$ E.g. Fahnestock \& Tonnard (2011); Snoeck Henkemans (2005a,b; 2007; 2008; 2009; 2011; 2017); Snoeck Henkemans \& Plug (2008); Tonnard (2011), van Eemeren \& Houtlosser (1999c; 2000b).
} 
sentence structure and idiomatic expressions show. ${ }^{7}$ In general, there is a growing body of literature offering a linguistically informed account of strategic linguistic choices in argumentation. Much of this literature is concerned with the question of how the semantic and pragmatic properties of - often conspicuous-words, idiomatic expressions, figures of speech, and categories of these, make them particularly appropriate in specific argumentative contexts.

An important and not unexpected conclusion that can be drawn from this kind of research is that generally there is an absence of one-to-one correspondence between a specific stylistic device and a specific strategic argumentative effect. A specific stylistic device can be used to achieve different strategic argumentative effects, and vice versa, a specific strategic argumentative effect can be achieved by choosing different stylistic devices. The relation between a certain specific presentational choice in designing an argumentative move and the strategic use of that argumentative move can only be established in the analysis of a specific speech event or a series of specific speech events in relation to their (institutional, situational and textual) context.

As I mentioned previously, discussion move choices, audiencedirected frames, and presentational devices are all relevant dimensions in the selection of an argumentative strategy, but presentational devices in general and stylistic choices in particular are the aspects of its realization and hence of its retrieval in analysis. It is therefore necessary to apply a systematic method of stylistic analysis as part of the analysis of strategic manoeuvring. More specifically, I would like to argue that we should choose the so-called "linguistic-stylistic analysis" as part of the analysis of strategic manoeuvring (see also van Haaften \& van Leeuwen 2018).

The basic assumption of the linguistic-stylistic approach is that language users almost always have a choice when describing a phenomenon or a state of affairs; this kind of alternative wording

\footnotetext{
${ }^{7}$ E.g. Boogaart (2013); Jansen (2009; 2011; 2016; 2017); Jansen, Dingemanse \& Persoon (2011); Tseronis, (2009); van Eemeren \& Houtlosser (1999a,b; 2000a; 2002); van Haaften (2017); van Haaften \& van Leeuwen (2018); Zarefsky (2006).

(C) Ton van Haaften. Informal Logic, Vol. 39, No. 4 (2019), pp. 301-328
} 
is considered to be a matter of "style." "Furthermore, it is assumed that stylistic variants are not interchangeable semantically. Hence, cases that are stylistically "neutral" simply do not exist. This assumption is adopted from the framework of Cognitive Linguistics and more specifically from the work of Ronald W. Langacker. Langacker (e.g. 1990) argues convincingly that the semantics of a grammatical form (a sentence, a phrase, a word) consist of two equally important components: a) the object to which the grammatical form refers and b) the way that object is conceptualised by the speaker, that is, the way the speaker wants the hearer to see the object; her/his "construal" of the object:

A speaker who accurately observes the spatial distribution of certain stars can describe them in many distinct fashions: as a constellation, as a cluster of stars, as specks of light in the sky, etc. Such expressions are semantically distinct; they reflect the speaker's alternate construals of the scene, each compatible with its objectively given properties (Langacker, 1990, p. 61).

Therefore, according to this assumption, different grammatical forms are related to distinct construals and thus to distinct meanings, even if they encode the same propositional content. Within the linguistic-stylistic approach, stylistic variants are considered to be grammatical forms with the same propositional content but with different construals (cf. Stukker \& Verhagen 2019). This holds for conspicuous stylistic variants (e.g. "inheritance tax" and "death tax") but also for less conspicuous or non-conspicuous ones (e.g. "husband" and "spouse"). In this sense, each stylistic choice can serve the purpose of framing the argumentative move that is formulated in such a way as to introduce a particular perspective.

The linguistic-stylistic method is further characterised by three methodological principles: 1) using a checklist of linguistic categories, 2) working comparatively, and 3) establishing specific communicative or interactional effects based on a semantic and pragmatic analysis of language forms used in the discourse (cf.

8 In a recent article, van Eemeren (2019) explores "the complex notion of argumentative style" theoretically. However, van Eemeren's (2019) notion of argumentative style encompasses much more than the choice of a particular verbal presentation and therefore differs from the notion of style used here.

(C) Ton van Haaften. Informal Logic, Vol. 39, No. 4 (2019), pp. 301-328 
Fahnestock 2011; van Haaften \& van Leeuwen 2018; Leech \& Short 2007; van Leeuwen 2015; Stukker \& Verhagen 2019).

The use of a stylistic checklist has been suggested at various times in linguistic and rhetorical approaches to style (cf. van Leeuwen 2015, pp. 26-28 and Stukker \& Verhagen 2019, pp. 5987 for an overview) and its added value lies in its heuristic function. A checklist can be designed in several different ways. The checklist formulated by Leech and Short (2007), for instance, in the context of their proposal for a systematic style analysis is primarily linguistic in nature; that is to say, it consists mainly of linguistic categories (see the Appendix). ${ }^{9}$ This checklist has two heuristic advantages. Firstly, the analyst is "forced" by this checklist to include a wide variation of stylistic devices in her/his analysis, including the less conspicuous or non-conspicuous ones. Secondly, the checklist also automatically directs the analyst's attention to grammatical-stylistic features; the list makes explicit that stylistic features occur at all "levels" of a text including at the grammatical level. The checklist is, therefore, an important tool to identify stylistic devices (cf. van Leeuwen 2014, pp. 237-238). Even so, the list is not a panacea. Working systematically through the checklist reduces the risk of overlooking pertinent stylistic devices, but it cannot remove this risk completely (cf. van Leeuwen 2014, p. 238). For one thing, the checklist is not exhaustive. A complete list would result in an instrument whose length would make it unmanageable in analytical practice. Furthermore, when identifying stylistic features in discourse, the analyst needs to be on the lookout not only for the presence of stylistic devices but also for their absence. Thus, style is not just a matter of using certain stylistic devices but, equally, of avoiding a particular kind of phrasing. And even when a checklist is used, identifying stylis-

\footnotetext{
${ }^{9}$ Leech \& Short (2007) developed their method, including the checklist, for the analysis of English fictional prose. However, their method is applicable not only to fictional prose (and other fictional genres) but also to non-fictional discourse genres. In general, the linguistic-stylistic approach assumes that style is a universal communicative phenomenon and that the method for style analysis with a linguistic foundation can be applied in all communicative domains because it is based on the semantic construal component of linguistic forms in a specific discourse in a specific language (cf. Stukker \& Verhagen 2019).
}

(C) Ton van Haaften. Informal Logic, Vol. 39, No. 4 (2019), pp. 301-328 
tic devices remains a partly intuitive process based on the knowledge of one or more analysts. If several analysts are involved in the stylistic analysis, then the analysis is naturally also more intersubjective.

It is therefore important to not only use a checklist for identifying stylistic devices but also to proceed by comparison. The possibly relevant presence or absence of stylistic devices in a certain piece of discourse is more easily brought to light if the analyst compares it to another relevant piece of discourse that is expressed in the same (discussion) context, for example, or that the analyst has created specially as a comparative criterion in the analysis. This manner of working reduces the risk of the analyst overlooking pertinent stylistic devices as does systematically running through a checklist. The outcome of using a checklist and working comparatively is a list of numerous linguistic phenomena that can be relevant for the stylistic analysis of a particular discourse. ${ }^{10}$

The core of the linguistic-stylistic method is the semantic and pragmatic analysis of language forms identified in the discourse with a view to establishing the specific communicative or interactional effects (cf. Leech \& Short 2007 and Verhagen \& Stukker 2019), which obviously presupposes a certain amount of linguistic background knowledge - behind every category mentioned in the checklist is a whole "world" of linguistics. The categories mentioned in the checklist are often not directly applicable in the analysis of the discourse; they need to be "translated." For example, the analyst needs to translate an abstract category like "suffixes" into a concrete stylistic phenomenon in the discourse, such as "plural," and then needs to analyse the communicative effect(s) of plurals in the specific discourse on the basis of their semantics and pragmatics.

In order to integrate a systematic linguistic-stylistic analysis of argumentative discourse into a general pragma-dialectical analysis, the following methodological steps are necessary (cf. van Haaften $\&$ van Leeuwen 2018). Firstly, the argumentative discourse has to

\footnotetext{
${ }^{10}$ See van Leeuwen (2015, pp. 36-39 and chapter 3) and Stukker \& Verhagen (2019, pp. 59-87) for a more detailed discussion of the methodology for using a linguistic checklist in stylistic analysis of fictional and non-fictional discourse.

(C) Ton van Haaften. Informal Logic, Vol. 39, No. 4 (2019), pp. 301-328
} 
be reconstructed in an analytic overview of the four discussion stages: the confrontation stage, the opening stage, the argumentation stage and the concluding stage. As part of this reconstruction, the specific dialectical and rhetorical aims of each discussion stage in the speech event(s) have to be determined. Secondly, strategic stylistic choices must be identified systematically. In the first phase of this stylistic analysis - the bottom-up analysis - specific stylistic devices are charted on the basis of working comparatively with the checklist. This analysis will result in a list of stylistic choices for the argumentative discourse that are assumed to be used in some form or another to manoeuvre strategically. In the second phase of the stylistic analysis, the obtained list of initial stylistic findings must be further reduced in a top-down analysis, given that our interest in conducting the analysis lies in the question of what stylistic devices are used strategically for the reconstruction of the goals envisaged by a speaker or writer. We must therefore establish or plausibly justify, for each of the stylistic devices identified in the bottom-up analysis, that (and how) they contribute to achieving the reconstructed strategic goals. This can be done by determining the (presumed) effect of the identified stylistic devices on the basis of semantic and pragmatic analysis of the language forms.

Finally, we must investigate whether argumentative strategies can be found within one or more discussion stages or within the discussion as a whole. In other words, we must check for the presence of coordinated stylistic choices in designing individual strategic manoeuvres to influence the result of a particular stage of the resolution process or the discussion as a whole. As I have already mentioned, I believe that one of the most important aims of a systematic linguistic-stylistic analysis of argumentative discourse is the identification and analysis of argumentative strategies. To achieve this, however, the analyst must first analyze the individual strategic manoeuvres, their presentational design, and the strategic effect of their presentational design. Following this, an analysis can be made of whether, and in what way, individual 
strategic manoeuvres contribute to one or more argumentative strategies. ${ }^{11}$

\section{An illustration: an argumentative strategy employed in the Dutch Lower House}

As observed earlier, the approach to the linguistic-stylistic analysis of argumentative strategies in argumentative discourse described above can not only be applied to a specific discussion or parts thereof (a speech event) but can also be used to identify and analyze argumentative strategies that are systematically employed in one or more corpora of several different discussions. To illustrate this, I will look in detail at one of the argumentative strategies used very frequently by the Dutch MP Mr Geert Wilders in debates in the Dutch Lower House. ${ }^{12}$

Mr Wilders is the leader of the Partij voor de Vrijheid (PVV, Party for Freedom), a populist political party on the extreme right which focuses on a single issue in its political programme: the danger of the Islamization of Dutch society. This party has held seats in the Dutch parliament since 2006 and has been quite successful in elections for the Dutch Lower House since then.

Wilders is not just well known for what he says but also attracts considerable attention with the way he puts his message into words. On the one hand, he is criticized for using expressions like "bonkers," "insane," and "raving mad" to characterize his opponents in parliamentary debates and in Dutch society as well as receiving criticism for using fallacies like argumentum ad bacu-

\footnotetext{
${ }^{11}$ In my view, integrating linguistic-stylistic analysis and pragma-dialectics is not only of instrumental value - at least if you start out from style analysis based on cognitive linguistics combined with the assumption of "argumentativity" (radical or otherwise) of natural language (Ducrot 2009; Stukker \& Verhagen 2019; Verhagen 2007) — but, as I see it, the theory on argumentative semantics and mental spaces elaborated in this approach can also make a significant theoretical contribution to the further development of thinking on strategic manoeuvring. It is not possible within the scope of this article to go into more detail here (but see van Haaften in preparation, "How to argue reasonably and effectively with style in Dutch").

12 The stylistic analysis reported in this section was performed in collaboration with Maarten van Leeuwen.
}

(C) Ton van Haaften. Informal Logic, Vol. 39, No. 4 (2019), pp. 301-328 
lum, argumentum ad hominem, argumentum ad populum, false analogy, secundum quid, slippery slope, straw man, falsely presenting something as a common starting point, evading the burden of proof and falsely presenting a standpoint or a premise as selfevident. On the other hand, he is able to formulate his standpoints very clearly as illustrated by the fact that in 2007 he won a "plain language award" from the Dutch National Youth Council.

Wilders' way of debating has therefore raised many questions and meta-political and meta-communicative discussions among citizens, journalists, opinion makers, and members of parliament about the nature of debate in the Dutch Lower House, and what kinds of contributions to a parliamentary debate are admissible or reasonable in the broadest sense. In general, it is quite clear that Wilders uses argumentative strategies that are at odds with the argumentative strategies used by most other members of the Dutch parliament. But in what way exactly and to what end?

In order to investigate the argumentative strategies used in parliamentary debates by Wilders and by other members of the Dutch parliament, a comparative analysis of their respective strategic language choices was made by applying the integrated argumentative and linguistic-stylistic analysis method explained above to a corpus of debates. ${ }^{13}$ The analysis revealed that Wilders uses several argumentative strategies, ${ }^{14}$ but a preferred and important discussion strategy he systematically employs is: "looking for confronta-

13 The corpus of debates was taken from the official Proceedings (in Dutch: Handelingen) of the Dutch Lower House via zoek.officielebekendmakingen.nl (last accessed on 3 May 2017). The corpus consists of plenary debates during the period 2006-2017. A random selection of debates from this corpus was analyzed using the version of Leech \& Short's checklist adapted for Dutch by van Leeuwen (2015, pp. 29-32).

${ }^{14}$ For a more detailed analysis of the argumentative strategies employed by Wilders in the Dutch Lower House, see van Haaften (2017). Wilders' presentational choices have been the object of study by other scholars as well but from different perspectives. Tonnard (2011), for example, gives a very interesting analysis of Wilders' strategic manoeuvring to get an issue that is a priority for his party on the table in a parliamentary debate; she also gives a detailed analysis from this perspective of Wilders' presentational choices. Van Leeuwen (2015) provides a very thorough analysis of Wilders' stylistic choices from the perspective of linguistic analysis but without establishing a link with argumentation.

(C) Ton van Haaften. Informal Logic, Vol. 39, No. 4 (2019), pp. 301-328 
tion by offering little or no room to exchange arguments about standpoints or sub-standpoints." This ensures that the debate gets little further than the confrontation of standpoints or substandpoints, rather than progressing to a full exchange of arguments so that the discussion remains "stuck" either in the confrontation stage or at the very beginning of the argumentation stage. Apart from the attitude adopted by Wilders in so-called "interruption debates," in which he regularly responds with "you can think that" or "then that is unfortunate," which instantly kills the debate, he also offers very little room for discussion in the way he formulates his standpoints and arguments. He does this by employing specific linguistic means which present his (sub)standpoints as self-evident or as indisputable facts, discourage further debate, or make it possible to use unclear language in a misleading way. Those linguistic means are as follows:

- The relative absence of subordinate clauses

- The use of the extremes of a semantic scale

- The use of the definite article 'the'

- The use of implicitness

The following section will illustrate which patterns of stylistic choices correspond with this argumentative strategy.

\subsection{The relative absence of subordinate clauses}

A characteristic of Wilders' language use is the relative absencein comparison to the argumentative language use of other representatives - of sentence structures with subordinate clauses. If you use a main clause with a subordinate clause, you often present your standpoint not as a fact but as an opinion, which offers room for discussion - an opening for other views or opinions about the same question. In a main clause plus subordinate clause, you generally present a particular point of view on the issue. Wilders' language use, by contrast, is characterised by the absence of this type of construction. Instead, he presents his (sub)standpoints as 
self-evident, as facts, which offers little or no room for discussion. Excerpt (1) illustrates this. ${ }^{15}$

(1) Madam Speaker, the Koran is a book that incites to violence. I remind the House that the distribution of such texts is unlawful according to Article 132 of our Penal Code. In addition, the Koran incites to hatred and calls for murder and mayhem; (...). The Koran is therefore a highly dangerous book; a book which is completely against our legal order and our democratic institutions. In this light, it is an absolute necessity that the Koran be banned for the defence and reinforcement of our civilization and our constitutional state. (...)

\subsection{Use of the extremes of a semantic scale}

Unlike many other Dutch politicians, Wilders often speaks in superlatives. He uses verbs and nouns that evoke strong emotions, often accompanied by adverbs and adjectives that also fall at the extreme end of a semantic scale (i.e. hyperbole). Excerpt (2) illustrates this:

(2) The Party for Freedom calls for a halt to immigration. The borders completely closed to immigrants from Muslim countries for five years. (...) After a hundred days, this Cabinet is already the world champion in the reasoning away of vitally important problems in Dutch society.

Speaking in superlatives makes it difficult to hold a "reasonable" discussion about the issues that Wilders raises. It is instantly all or nothing; he offers no room for a middle way.

\subsection{Definite articles}

Wilders speaks systematically about "the Dutch citizens," "the Islam," "the elite," etc. In so doing, he uses apparently univocal clearly demarcated categories, which offers no room for a discussion about the diversity found within such a group or phenomenon and which are often also expressions of overhasty generalization. Excerpt (3) illustrates this:

\footnotetext{
15 The excerpts (1) to (4) below are taken from the random selection of debates from a larger corpus of debates, see footnote 13; the translation of the excerpts from Dutch into English is mine.
}

(C) Ton van Haaften. Informal Logic, Vol. 39, No. 4 (2019), pp. 301-328 
(3) The majority of the Dutch citizens have become fully aware of the danger, and regard the Islam as a threat to our culture. (...) However, their representatives in The Hague are doing precisely nothing. (...)

\subsection{Implicitness}

With some regularity, and relatively more than his fellow representatives, Wilders formulates his standpoints in an implicit way. In these cases, he does not make his standpoint explicit but merely creates the suggestion that he adopts a certain standpoint This can be seen in the following excerpt:

(4) Mr Wilders: "However, even established political parties are waking up. This is something new. Christian Democrats in Germany are starting to understand it more and more. (...) The party leader of the CSU, Horst Seehofer, actually goes even further. He wants a complete halt to the immigration of Turks and Arabs to Germany. (...) He says: "multiculti is dead." Even the German Chancellor, Mrs Merkel, says that the multicultural society has proved to be an absolute failure. Not a slight failure, but an absolute failure. If she says that, it is saying quite a lot. (...)"

Mrs Halsema (GreenLeft): You are saying: Islam does not belong in our country. At least, that is what I assume.

Mr Wilders: No, I did not say that.

Mrs Halsema: No, but you quote German politicians and I assume that this is what you mean.

Mr Wilders: No, I only quoted them.

Mrs Halsema: Are you now standing there, quoting all those German politicians because they are so brave and dare to say all that, and then conclude that you do not dare to say it yourself?

Mr Wilders: I used a quotation, nothing more.

In this example, Wilders creates the suggestion that he thinks Islam does not belong in the Netherlands. Not making that standpoint explicit can also be seen as a linguistic choice that makes it 
difficult for his political opponents to engage in debate with him on this position. Because Wilders formulates his standpoint so implicitly, he offers less room for discussion than if he were to state this standpoint explicitly. He uses this device, in fact, to try to evade his burden of proof. Moreover, it offers him the opportunity to adopt a "victim position"-along the lines of: "a standpoint is being foisted onto me" - so that he can easily accuse the other party of committing a variant of the straw man fallacy.

Thus, the comparison between the stylistic choices of Wilders and those of other members of parliament reveals substantial differences. Other members of parliament use more subordinate clauses, avoid over-use of the extremes on the semantic scale, and make less use of the definite article "the" and of implicitness as a way to avoid further discussion. In general, other representatives formulate their strategic manoeuvres in such a way as to express willingness to exchange arguments about their (sub)standpoints. They also anticipate doubt about their standpoints or arguments and express willingness to defend them. More so than Wilders, they exhibit willingness to discuss the merits of an issue. Probably because of this, they use mitigating words and phrases more often than intensifying ones, more abstract than concrete nouns, and more jargon.

\section{Conclusion}

My aim in this article was to show how argumentative strategies in argumentative discourse can be identified and analysed using a systematic linguistic-stylistic analysis within a pragma-dialectic perspective. It is important to identify and analyze argumentative strategies because they contribute to the persuasive power of argumentative discourse and substantially determine the course taken by a discussion. Therefore, systematic attention should be given to the various kinds of argumentative strategies and the distinctions between them in order to achieve a profound, realistic and accurate reconstructive analysis and an adequate evaluation of argumentative discourse.

The initial starting point for identifying argumentative strategies is the analysis of presentational devices and especially lin- 
guistic devices. Choice of discussion moves, audience-directed frames, and presentational devices are all relevant dimensions in the selection of an argumentative strategy but presentational devices in general and strategic stylistic choices in particular are the points of its realisation and hence of its retrieval in analysis. It is necessary to apply a systematic method of stylistic analysis for the identification and analysis of argumentative strategies. More specifically, I have argued that for this a linguistic-stylistic method is the best option.

Nevertheless, as I noted earlier, the linguistic-stylistic method is not a panacea. Going systematically through the checklist, for example, reduces the risk of overlooking pertinent stylistic devices and their systematic relation to other devices, but it cannot eliminate this risk completely (cf. Van Leeuwen 2014: 238). For one thing, the checklist is not exhaustive. A complete list would result in an instrument whose length would make it unmanageable in analytical practice. In addition, the method presupposes a great deal of linguistic background knowledge; behind every category mentioned in the checklist, there hides a whole "world" of linguistics. This may hamper the linguistic-stylistic analysis because the categories mentioned in the checklist are often not directly applicable to the analysis of specific discourses. For instance, category A1 in the checklist proposed by Leech \& Short (2007) (see the Appendix) directs the analyst to search for the use of "specific types of vocabulary," among other things. This helped to identify Wilders' strategic use of extremes on a semantic scale (see section 4.2), but the "translation" from an abstract category like "specific types of vocabulary" to a concrete stylistic phenomenon like "extreme on a semantic scale" is something that the analyst needs to do her/himself based on linguistic knowledge. However, this is a problem of stylistic research in general, and even without the use of a linguistic checklist, the problem would still exist. Thus, all in all, the linguistic-stylistic method does not provide a panacea for identifying and analyzing argumentative strategies; it does not reduce this to a relatively uncomplicated activity. Yet I hope, nonetheless, to have shown that this method can provide a valuable contribution to identifying and analyzing argumentative strategies in a systematic way. 


\section{Appendix}

A checklist of linguistic and stylistic categories (Leech and Short 2007)

\section{A: Lexical categories}

1. GENERAL. Is the vocabulary simple or complex? Formal or colloquial? Descriptive or evaluative? General or specific? How far does the writer make use of the emotive and other associations of words, as opposed to their referential meaning? Does the text contain idiomatic phrases or notable collocations, and if so, with what kind of dialect or register are these idioms or collocations associated? Is there any use of rare or specialized vocabulary? Are any particular morphological categories noteworthy (e.g. compound words, words with particular suffixes)? To what semantic fields do words belong?

2. NOUNS. Are the nouns abstract or concrete? What kinds of abstract nouns occur (e.g. nouns referring to events, perceptions, processes, moral qualities, social qualities)? What use is made of proper names? Collective nouns?

3. ADJECTIVES. Are the adjectives frequent? To what kinds of attribute do adjectives refer? Physical? Psychological? Visual? Auditory? Colour? Referential? Emotive? Evaluative? etc. Are adjectives restrictive or non-restrictive? Gradable or nongradable? Attributive or predicative?

4. VERBS. Do the verbs carry an important part of the meaning? Are they stative (referring to states) or dynamic (referring to actions, events, etc.)? Do they 'refer' to movements, physical acts, speech acts, psychological states or activities, perceptions, etc.? Are they transitive, intransitive, linking (intensive), etc.? Are they factive or non-factive?

5. ADVERBS. Are adverbs frequent? What semantic functions do they perform (manner, place, direction, time, degree, etc.)? Is there any significant use of sentence adverbs (conjuncts such 
as so, therefore, however; disjuncts such as certainly, obviously, frankly)?

\section{B: Grammatical categories}

1. SENTENCE TYPES. Does the author use only statements (declarative sentences), or do questions, commands, exclamations or minor sentence types (such as sentences with no verb) also occur in the text? If these other types appear, what is their function?

2. SENTENCE COMPLEXITY. Do sentences on the whole have a simple or complex structure? What is the average sentence length (in number of words)? What is the ratio of dependent to independent clauses? Does complexity vary strikingly from one sentence to another? Is complexity mainly due to (i) coordination, (ii) subordination, or (iii) parataxis (juxtaposition of clauses or other equivalent structures)? In what parts of a sentence does complexity tend to occur? For instance, is there any notable occurrence of anticipatory structure (e.g. of complex subjects preceding the verbs, of dependent clauses preceding the subject of a main clause)?

3. CLAUSE TYPES. What types of dependent clause are favored: relative clauses, adverbial clauses, different types of nominal clauses (that-clauses, wh-clauses, etc.)? Are reduced or non-finite clauses commonly used and, if so, of what type are they (infinitive clauses, -ing clauses, -ed clauses, verbless clauses)?

4. CLAUSE STRUCTURE. Is there anything significant about clause elements (e.g. frequency of objects, complements, adverbials; of transitive or intransitive verb constructions)? Are there any unusual orderings (initial adverbials, fronting of object of complement, etc.)? Do special kinds of clause construction occur (such as those with preparatory it or there)?

5. NOUN PHRASES. Are they relatively simple or complex? Where does the complexity lie (in premodification by adjec- 
tives, nouns, etc., or in postmodification by prepositional phrases, relative clauses, etc.)? Note occurrence of listings (e.g. sequences of adjectives), coordination or apposition.

6. VERB PHRASES. Are there any significant departures from the use of the simple past tense? For example, notice occurrences and functions of the present tense; of the progressive aspect (e.g. was lying); of the perfective aspect (e.g. has/had appeared); of modal auxiliaries (e.g. can, must, would, etc.) Look out for phrasal verbs and how they are used.

7. OTHER PHRASE TYPES. Is there anything to be said about other phrase types: prepositional phrases, adverb phrases, adjective phrases?

8. WORD CLASSES. Having already considered major or lexical word classes, we may here consider minor word classes ('function words'): prepositions, conjunctions, pronouns, determiners, auxiliaries, interjections. Are particular words of these types used for particular effect (e.g. the definite or indefinite article; first person pronouns I, we, etc.; demonstratives such as this and that; negative words such as not, nothing, no)?

9. GENERAL. Note here whether any general types of grammatical construction are used to special effect; e.g. comparative or superlative constructions; coordinative or listing constructions; parenthetical constructions; appended or interpolated structures such as occur in casual speech. Do lists and coordinations (e.g. lists of nouns) tend to occur with two, three or more than three members? Do the coordinations, unlike the standard construction with one conjunction (sun, moon and stars), tend to omit conjunctions (sun, moon, stars) or have more than one conjunction (sun and moon and stars)?

\section{C: Figures of speech, etc.}

Here we consider the incidence of features which are foregrounded by virtue of departing in some way from general norms of communication by means of the language code; for example, exploita- 
tion code. For identifying such features, the traditional figures of speech (schemes and tropes) are often useful categories.

1. GRAMMATICAL AND LEXICAL. Are there any cases of formal and structural repetition (anaphora, parallelism, etc.) or of mirror-image patterns (chiasmus)? Is the rhetorical effect of these one of antithesis, reinforcement, climax, anticlimax, etc.?

2. PHONOLOGICAL SCHEMES. Are there any phonological patterns of thyme, alliteration, assonance, etc.? Are there any salient rhythmical patterns? Do vowel and consonant sounds pattern or cluster in particular ways? How do these phonological features interact with meaning?

3. TROPES. Are there any obvious violations of, or departures from, the linguistic code? For example, are there any neologisms (such as Americanly)? Deviant lexical collocations (such as portentous infants)? Semantic, syntactic, phonological, or graphological deviations? Such deviations (although they can occur in everyday speech and writing) will often be the clue to special interpretations associated with traditional poetic figures of speech such as metaphor, metonymy, synecdoche, paradox and irony. If such tropes occur, what kind of special interpretation is involved (e.g. metaphors can be classified as personifying animising, concretising, synaesthetic, etc.)? Because of its close connection with metaphor, simile may also be considered here. Does the text contain any similes, or similar constructions (e.g. 'as if' constructions)? What dissimilar semantic fields are related through simile?

\section{D: Context and cohesion}

- Cohesion: ways in which one part of a text is linked to another (the internal organisation of the text).

- Context: the external relations of a text or a part of a text, seeing it as a discourse presupposing a social relation between its participants (author and reader; character and character, etc.), and a sharing by participants of knowledge and assumptions. 
1. COHESION. Does the text contain logical or other links between sentences (e.g. coordinating conjunctions, or linking adverbials)? Or does it tend to rely on implicit connections of meaning? What sort of use is made of cross-reference by pronouns (she, it, they, etc.)? By substitute forms (do, so, etc.), or ellipsis? Alternatively, is any use made of elegant variation the avoidance of repetition by the substitution of a descriptive phrase (as, for example, 'the old lawyer' or 'her uncle' may substitute for the repetition of an earlier 'Mr Jones')? Are meaning connections reinforced by repetition of words and phrases, or by repeatedly using words from the same semantic field?

2. CONTEXT. Does the writer address the reader directly, or through the words or thoughts of some fictional character? What linguistic clues (e.g. first-person pronouns I, me, my, mine) are there of the addresser-addressee subject? If a character's words or thoughts are represented, is this done by direct quotation (direct speech), or by some other method (e.g. indirect speech)? Are there significant changes of style according to who is supposedly speaking or thinking the words on the page?

\section{References}

Boogaart, R.J.U. 2013. Strategische manoeuvres met sterke drank: redelijk effectief? [Strategic manoeuvres with hard liquor: Reasonably effective?]. In Neerlandistiek in Beeld, eds. A.J.M. Janssen \& T. van Strien, 283-292. Amsterdam/Münster: Stichting Neerlandistiek VU/Nodus Publikationen.

Ducrot, O. 2009. Slovenian lectures: Introduction into argumentative semantics. Ljubljana: Pedagoški inštitut.

Eemeren, F.H. van. 2010. Strategic maneuvering in argumentative discourse. Amsterdam etc: John Benjamins.

Eemeren, F.H. van. 2018. Argumentation theory: A pragma-dialectical perspective. Cham: Springer.

Eemeren, F.H. van, 2019. Argumentative style: a complex notion. Argumentation 33: 153-171.

Eemeren, F.H. van and P. Houtlosser. 1999a. Strategic manoeuvring in argumentative discourse. Discourse Studies 1: 479-497.

(C) Ton van Haaften. Informal Logic, Vol. 39, No. 4 (2019), pp. 301-328 
Eemeren, F.H. van and P. Houtlosser. 1999b. Over zekere waarden. Een analyse van twee objectief waarderende standpunten. [On certain values. An analysis of two objectively evaluative standpoints.] Tijdschrift voor Taalbeheersing, 21: 179-186.

Eemeren, F.H. van and P. Houtlosser. 1999c. William the Silent's argumentative discourse. In Proceedings of the fourth conference of the International Society for the Study of Argumentation, eds. F.H. van Eemeren, R. Grootendorst, J.A. Blair and C.A Willard, 168-171. Amsterdam: Sic Sat.

Eemeren, F.H. van and P. Houtlosser. 2000a. Rhetorical analysis within a pragma-dialectical framework. The case of R.J. Reynolds. Argumentation 14: 293-305.

Eemeren, F.H. van and P. Houtlosser. 2000b. De retorische functie van stijlfiguren in een dialectisch proces: strategisch gebruikte metaforen in Edward Kennedy's Chappaquiddick speech. [The rhetorical function of figures of speech in a dialectical process: Strategically used metaphors in Edward Kennedy's Chappaquiddick speech.] In Over de grenzen van de taalbeheersing, eds. R. Neutelings, N. Ummelen \& A. Maes, 151-162. Den Haag: SDU Uitgevers.

Eemeren, F.H. van and P. Houtlosser. 2002. Strategic maneuvering in argumentative discourse: A delicate balance. In Dialectic and rhetoric: The warp and woof of argumentation analysis, eds. F.H. van Eemeren and P. Houtlosser, 131-159. Dordrecht etc.: Kluwer.

Fahnestock, J. 2009. Quid pro nobis. Rhetorical stylistics for argument analysis. In examining argumentation in context. Fifteen studies on strategic maneuvering, ed. F. H. van Eemeren, 191-220. Amsterdam etc.: John Benjamins.

Fahnestock, J. 2011. Rhetorical Style. The uses of Language in Persuasion. Oxford: OUP.

Fahnestock, J. and Y. Tonnard. 2011. Amplification in strategic maneuvering. In Keeping in touch with Pragma-Dialectics, eds. E. Feteris, B. Garssen and F. Snoeck Henkemans, 103-116. Amsterdam etc.: John Benjamins.

Haaften, T. van. 2017. Strategic maneuvering with presentational choices in Dutch parliamentary debate. In Contextualizing PragmaDialectics, eds. F.H. van Eemeren and P. Wu, 177-192. Amsterdam etc: John Benjamins.

Haaften, T. van and M. van Leeuwen. 2018. Strategic maneuvering with presentational devices: A systematic approach. In Argumentation and Inference. Proceedings of the 2nd European Conference on Argu- 
mentation, Fribourg 2017, Volume II. Studies in Logic 76, eds. S. Oswald and D. Maillat, 873-886. London: College Publications.

Jansen, H. 2009. Legal arguments about plausible facts and their strategic presentation. In Argument Cultures. Proceedings of the 8th OSSA Conference, June 2009, ed. J. Ritola, CD. Windsor, Canada: University of Windsor.

Jansen, H. 2011. "If that were true, I would never have ..." The counterfactual presentation of arguments that appeal to human behaviour. In Proceedings of the seventh conference of the International Society for the Study of Argumentation, eds. F.H. van Eemeren, B.J. Garssen, D. Godden \& G. Mitchell, CD. Amsterdam: Sic Sat.

Jansen, H. 2016. Strategic maneuvering with that says it all and that says everything. In Argumentation and Reasoned Action. Proceedings of the 1st European Conference on Argumentation, Lisbon 2015, Volume II, eds. D. Mohammed and M. Lewiński, 587-599. College Publications.

Jansen, H.. 2017. The strategic formulation of abductive arguments in everyday reasoning. In Argumentation, objectivity, and bias: Proceedings of the 11th International Conference of the Ontario Society for the Study of Argumentation (OSSA), 18-21 May 2016, eds. P. Bondy and L. Benacquista, 1-10. Windsor, ON: OSSA.

Jansen, H., Dingemanse, M. and I. Persoon. 2011. Limits and effects of reductio ad absurdum argumentation. In Bending opinion. Essays on persuasion in the public domain, eds. T. van Haaften, H. Jansen, J. de Jong and W. Koetsenruijter, 143-158. Leiden: Leiden University Press.

Langacker, R.W. 1990. Concept, image and symbol: The cognitive basis of grammar. Berlin: Mouton de Gruyter.

Leech, G. and Short, M. 2007. Style in fiction. A linguistic introduction to English fictional prose (second edition). Harlow: Pearson Longman.

Leeuwen, M. van. 2014. Systematic stylistic analysis. The use of a checklist. In From text to political positions. Text analysis across disciplines, eds. B. Kaal, I. Maks and A. van Elfrinkhof, 225-244. Amsterdam etc.: John Benjamins.

Leeuwen, M. van. 2015. Stijl en politiek. Een taalkundig-stilistische benadering van Nederlandse parlementaire toespraken. [Style and politics. A linguistic-stylistic approach to Dutch parliamentary speeches] Dissertation Leiden University. Utrecht: LOT. 
Perelman, C. and L. Olbrechts-Tyteca. 1969. The new Rhetoric. A treatise on argumentation (Trans.). Notre Dame: University of Notre Dame Press. (original work published in 1958)

Poppel, L. van. 2016. Strategisch manoeevreren met Litotes. [Strategic maneuvering with Litotes]. In De macht van de taal. Taalbeheersingsonderzoek in Nederland en Vlaanderen, eds. D. De Mieroop, R. Buysse, R. Coesemans and P. Gillaerts, 219-232. Leuven: Acco.

Snoeck Henkemans, A.F. 2005a. Strategisch manoeuvreren met metonymie. [Strategic Maneuvering with metonymy.] Tijdschrift voor Taalbeheersing 27: 245-257.

Snoeck Henkemans, A.F. 2005b. What's in a name? The use of the stylistic device metonymy as a strategic manoeuvre in the confrontation and argumentation stages of a discussion. In Proceedings of conference, ed. D. Hitchcock, 433-441. Hamilton: Ontario Society for the Study of Argumentation.

Snoeck Henkemans, A.F. 2007. Manoeuvring strategically with rhetorical questions. In Proceedings of the sixth conference of the International Society for the Study of Argumentation, eds. F.H. van Eemeren, J.A. Blair, C.A. Willard and B. Garssen (Eds.) 1309-1315. Amsterdam: Sic Sat.

Snoeck Henkemans, A.F. 2008. De stijlfiguur praeteritio als middel om strategisch te manoeuvreren. [The figure of speech praeteritio as a means to maneuver strategically.] Tijdschrift voor Taalbeheersing 30: 133-146.

Snoeck Henkemans, A.F. 2009. Manoeuvring strategically with 'praeteritio.' Argumentation 23: 339- 350.

Snoeck Henkemans, A.F. 2011. The contribution of praeteritio to arguers' strategic maneuvering in the argumentation stage of a discussion. In Bending opinion. Essays on persuasion in the public domain, eds. T. van Haaften, H. Jansen, J.C. de Jong and W. Koetsenruijter, 133143. Leiden: Leiden University Press.

Snoeck Henkemans, A.F. 2013. The use of hyperbole in the argumentation stage. In Virtues of Argumentation. Proceedings of the 10th International Conference of the Ontario Society for the Study of Argumentation (OSSA), 22-26 May 2013, eds. D. Mohammed and M. Lewiński, 1-9. Windsor, ON: OSSA.

Snoeck Henkemans, A.F. 2017. Strategic manoeuvring with hyperbole in political debate. In Contextualizing pragma-dialectics, eds. F.H. van Eemeren and P. Wu, 269-280. Amsterdam etc: John Benjamins.

Snoeck Henkemans, A.F. and H.J. Plug. 2008. Apologies for metaphors as a strategic manoeuvre in political debates. In Rhetorical aspects of 
discourses in present-day society, eds. L. Dam, L. Holmgreen and J. Strunck, 102-117. Cambridge: Cambridge Scholars Press.

Stukker, N. and A. Verhagen 2019. Stijl, taal en tekst: stilistiek op taalkundige basis. [Style, language and text: stylistics on a linguistic foundation.] Leiden: Leiden University Press.

Tseronis, A. 2009. Qualifying standpoints. Stance adverbs as a presentational device for managing the burden of proof. Dissertation Leiden University. Utrecht: LOT.

Tseronis, A. 2017. Analysing multimodal argumentation within the pragma-dialectical framework. In Contextualizing pragma-dialectics, eds. F.H. van Eemeren and P. Wu, 335-359. Amsterdam etc: John Benjamins.

Tonnard, Y. 2011. Getting an issue on the table: A pragma-dialectical study of presentational choices in confrontational strategic maneuvering in Dutch parliamentary debate. Dissertation University of Amsterdam. Alblasserdam: Haveka.

Verhagen, A. 2007. Constructions of Intersubjectivity: Discourse, Syntax, and Cognition. Oxford: Oxford University Press.

Zarefsky, D. 2006. Strategic maneuvering through persuasive definitions: Implications for dialectic and rhetoric. Argumentation 20: 399416. 